\title{
EFFECTS OF POTASSIUM ON PHENOLOGICAL, PHYSIOLOGICAL AND AGRONOMIC TRAITS OF MAIZE (ZEA MAYS L.) UNDER HIGH NITROGEN NUTRITION WITH OPTIMUM AND REDUCED IRRIGATION
}

\author{
SHAH, T. $.^{1,2}-$ KHAN, H. ${ }^{1}-$ NOOR, M. A..$^{3 *}$ GHONEIM, A. ${ }^{4}-$ WANG, X.$^{5 *}$ SHER, A. ${ }^{6}-$ \\ NASIR, M. ${ }^{7}-$ BASAHI, M. A. ${ }^{8}$ \\ ${ }^{1}$ Department of Agronomy, University of Agriculture, Peshawar, Pakistan
}

${ }^{2}$ Key Laboratory of Oil Crop Biology and Genetic Improvement, Oil Crops Research Institute of the Chinese Academy of Agricultural Sciences, Wuhan, Hubei, China

${ }^{3}$ Institute of Crop Sciences, Chinese Academy of Agricultural Sciences, Key Laboratory of Crop Physiology and Ecology, Ministry of Agriculture, 100081 Beijing, China

${ }^{4}$ Department of Soil Sciences, College of Food and Agricultural Sciences, King Saud University, P.O. Box 2460, Riyadh 11451, Saudi Arabia

${ }^{5}$ College of Life Sciences, Yan'an University, 716000 Yan'an, Shaanxi, China

${ }^{6}$ School of Agronomy, Anhui Agricultural University, Hefei 230036, Anhui, China

${ }^{7}$ College of Natural Resources and Environment, Northwest Agriculture and Forestry University, 712100 Yangling, China

${ }^{8}$ Dept. of Biology, College of Science \& Arts, Sajir, Shaqra University P.O. Box-33, 11961 Shaqra, Saudi Arabia

*Corresponding authors

e-mail:mehmood2017@gmail.com (M.A. Noor);wangxiukang@126.com (X.Wang)

(Received 30 $0^{\text {th }}$ Jul 2018; accepted $8^{\text {th }}$ Oct 2018)

\begin{abstract}
Potassium (K) as a macro nutrient governs important physiological mechanisms ensuring optimum plant growth and produce quality. An experiment was conducted during the summer of 2017 to study the effects of potassium application on maize under high nitrogen $(\mathrm{N})$ nutrition with optimum and reduced irrigations. The experiment was comprised of three factors, viz. two irrigation levels (optimum, reduced), three potassium levels $\left(80,120\right.$ and $\left.160 \mathrm{~kg} \mathrm{ha}^{-1}\right)$ and four nitrogen levels (100, 150, 200 and $250 \mathrm{~kg} \mathrm{ha}^{-1}$ ). Two separate trials were carried out in randomized complete block design (RCBD), one under optimum (five irrigations) and another under reduced irrigation (three irrigations). One control plot $(0 \mathrm{~K}, 0 \mathrm{~N})$ was used under each replication for both trials. Optimum irrigation had resulted in maximum days of tasseling, silking, physiological maturity, crop growth rate (CGR), net assimilation rate (NAR), absolute growth rate (AGR), plant height, grains ear ${ }^{-1}$, thousand grains weight, biological yield, grain yield, chlorophyll contents and shelling percentage. High $\mathrm{N}\left(250 \mathrm{~kg} \mathrm{ha}^{-1}\right)$ delayed tasseling, silking and physiological maturity and resulted in maximum growth, physiological traits and biological yields. However, $150 \mathrm{~kg} \mathrm{~N} \mathrm{ha}^{-1}$ had resulted in maximum number of ears $\mathrm{m}^{-2}$, number of grains ear ${ }^{-1}$, thousand grains weight and grain yield. While $100 \mathrm{~kg} \mathrm{~N} \mathrm{ha}^{-1}$ had resulted in early tasseling, silking and physiological maturity. Potassium fertilization at the rate of $160 \mathrm{~kg} \mathrm{ha}^{-1}$ delayed phenology and recorded with maximum growth rates, improved physiology and maximum yield traits and grain yield. However, the treatment $120 \mathrm{~kg} \mathrm{~K} \mathrm{ha}^{-1}$ remained almost statistically similar to the $160 \mathrm{~kg} \mathrm{~K} \mathrm{ha}^{-1}$ for most of the parameters. In the case of control vs rest, generally the performance of the control plot was poor. Hence, $150 \mathrm{~kg} \mathrm{~N} \mathrm{ha}^{-1}$ with $120 \mathrm{~kg} \mathrm{~K} \mathrm{ha}^{-1}$ under optimum irrigation is recommended for optimum productivity of maize crop.
\end{abstract}

Keywords: fertilizer rate, maize, deficit irrigation, ear characteristics, grain yield 


\section{Introduction}

Maize (Zea mays L.) is the third most important cereal crop in Pakistan after wheat and rice and ranks second in Khyber Pakhtunkhwa province after wheat. Maize is cultivated in Pakistan on 64\% irrigated and 36\% on rainfed land (Ahmad and Rashid, 2003). Implementation and adoption of the new production technologies had increased the maize production per unit area due to balance use of agriculture inputs and new methods (Amanullah, 2004).

Improper application of the synthetic fertilizers in Khyber Pakhtunkhwa is the main cause of low yield of maize (Amanullah et al., 2014). In Pakistan only tobacco crop receive potassium due to industrial requirement while farmers do not apply potassium to wheat and maize in general. Deficiency of potassium is reported in most of the Pakistani soils due to multiple cropping systems (Ahmad and Rashid, 2003). Potassium is used by the crops in large amounts (Mengel et al., 2001; White and Karley, 2010). A soil deficient in potassium results in reduced plant photosynthesis (Wang et al., 2015a), which is the main cause of low yield of maize (Amanullah and Khalid, 2016), sunflower (Amanullah and Khan, 2010) and brassica (Amanullah et al., 2011).

Potassium is the primary major nutrient which is a non-structural component of the plant body. After nitrogen it is the second most abundant nutrient in plant tissues generally $1-3 \%$ by weight. It is very important for the transport of assimilates in plant cells and activates more than 60 different enzymes. Potassium increases plant tolerance to frost and heat injuries, droughts and enhances the resistance to diseases, different pest incidence and keeps anion balance in plants (Wang et al., 2013). The most important role of $\mathrm{K}^{+}$in plants is the osmoregulation which maintains turgor pressure in the cell, crucial for cell elongation and hence the growth and regulation of stomatal opening and closing, affecting carbon dioxide intake by photosynthesis process and transpirational cooling (Marschner, 1995). Potassium is a macro nutrient which is important for the growth of plants. Comparatively the large amounts of mineral potassium are present in the Pakistani soil which is non-soluble, and only a small amount is available to plants. Optimum amount of potassium in the soil in case of water scarcity comparatively enhances deposition of total dry matter in the crops compared to soils with less potassium regimes (Rosenstock et al., 2016). Potassium regulates stomata which in turn enhance photosynthesis (Marschner, 2012). Moreover, the root growth is supported by the crucial role of potassium in the transportation of photosynthetic products (Romheld and Kirkby, 2010).

Being a macro-nutrient, nitrogen is essential for the plant health and acts as a growthlimiting nutrient (Noor, 2017; Wang et al., 2018). Nitrogen is the major part of several essential organic compounds such as amino acids, proteins, coenzymes, nucleic acids, chlorophyll, cytochrome, ribosomes and many vitamins (Noorka et al., 2009, 2011). Among various grasses, maize is the grass whose nitrogen requirements for optimum grain yield is very high (Noor, 2017). Certain metabolic processes of the plants depend on the role of nitrogen in plants (Wang et al., 2015b). During the whole grain-filling stage, it aids to keep the kernels active, affecting the size and number of improved kernels (Huber et al., 1994). Usually nitrogen demand of maize is very different, and approximately $0-250 \mathrm{~kg} \mathrm{~N}^{-1}$ is the range for economically optimal nitrogen rates (EONR) (Scharf et al., 2006). Therefore, it is imperative to manage nitrogenous fertilizers accurately (Noor, 2017), but the capacity to determine the exact EONR had been kept comparatively elusive. 
A sufficient amount of water in the soil is important for the growth and development of crops, recovery of water loss through transpiration and as a transport medium for nutrients to roots (Wang et al., 2018). Scarce availability of water to crops in the soil leads to drought. Acute water deficiency reduces water use and hence crop yield. There are three big processes by which maize yield is limited by water scarcity in the soil: (i) decreased absorption of the incident photosynthetically active radiation by canopy, (ii) reduced radiation use efficiency, (iii) decreased harvest index (Earl and Davis, 2003).

To know and keeping in mind the importance of potassium, in case of high nitrogen nutrition impact on maize lodging under optimum and reduced irrigations, the present experiment was designed and conducted to find out optimum level of potassium for improved growth and yield traits by minimizing lodging losses, enhancing resistance to drought and to figure out the best nitrogen level for higher maize productivity in the agro-climatic conditions of Peshawar, Pakistan.

\section{Materials and methods}

\section{Site description}

Field experiments were conducted to study the response of spring planted maize hybrid, at Agronomy Research Farm, The University of Agriculture Peshawar, Pakistan, during the summer of 2017 . The research farm is located at $34.01^{\circ} \mathrm{N}, 71.35^{\circ} \mathrm{E}$, at an altitude of $350 \mathrm{~m}$ above sea level in the Peshawar valley (Fig. 1). Peshawar is located about $1600 \mathrm{~km}$ north of the Indian Ocean and has semiarid climate. The research farm is irrigated by the Warsak canal from Kabul River. The soil of the farm is clay loam in texture, alkaline ( $\mathrm{pH} 8.2$ ), and calcareous, with a low organic matter content of 8.7 (g $\mathrm{kg}^{-1}$ ) and low concentrations of extractable phosphorus of $6.57 \mathrm{mg} \mathrm{kg}^{-1}$ and exchangeable potassium (AB-DTPA) of $121\left(\mathrm{mg} \mathrm{kg}^{-1}\right)$. The climate of the area is semiarid where the mean annual rainfall is very low (300 to $500 \mathrm{~mm}$ ), $60-70 \%$ rainfall occurs in summer, while the remaining $30-40 \%$ rainfall occurs in winter.

\section{Experimental treatments and management practices}

Two trials, one with optimum irrigation (I) (I = 5 irrigations) and another with reduced irrigation $\left(\mathrm{I}_{2}=3\right.$ irrigations) were carried out in randomized complete block design (RCBD). Nitrogen $\left(\mathrm{N}_{1}=100, \mathrm{~N}_{2}=150, \mathrm{~N}_{3}=200\right.$ and $\left.\mathrm{N}_{4}=250 \mathrm{~kg} \mathrm{ha}^{-1}\right)$ and potassium $\left(\mathrm{K}_{1}=80, \mathrm{~K}_{2}=120\right.$ and $\left.\mathrm{K}_{3}=160 \mathrm{~kg} \mathrm{ha}^{-1}\right)$ were applied in combination to both experiments with three replications. Each replication was added with an unfertilized plot (0N, 0K). CS-220 variety of maize was sown on $18^{\text {th }}$ May 2017 with a sub-plot area of $3 \mathrm{~m} \times 4 \mathrm{~m}$, which was consisted of $70 \mathrm{~cm}$ apart $3 \mathrm{~m}$ long 5 rows. Seeds were planted at the rate of $35 \mathrm{~kg} \mathrm{ha}^{-1}$. Before seed bed preparation, presoaking irrigation of $100 \mathrm{~mm}$ was given. When the soil reached at field capacity, seedbed was prepared. Subsequently, five irrigations (75 mm each) were applied at VE, V6, V12, V18 and R1 stages of maize for optimum irrigation treatment. For the reduced irrigation, three irrigations (75 mm each) were applied at VE, V12 and R1 stages of maize. Muriate of potash (MOP) was used as a source of potassium which contains $60 \% \mathrm{~K}_{2} \mathrm{O}$, Similarly $\mathrm{N}$ was applied as urea $(46 \% \mathrm{~N})$. Source of phosphorus was triple super phosphate (TSP) at the rate of $90 \mathrm{~kg} \mathrm{ha}^{-1}$. Potash and phosphorus were applied as a whole at the planting time, whereas half split of nitrogen was applied at planting and the other half at V6 stage (knee height). Weeds were controlled by applying herbicide Primixtra gold (S- 
Metolachlor $400 \mathrm{~g} / \mathrm{L}$, Atrazine $320 \mathrm{~g} / \mathrm{L}$ ) at rate of $2000 \mathrm{ml} \mathrm{ha}^{-1}$ two weeks after sowing maize crop. On the basis of calibration for experimental area, $2501 \mathrm{ha}^{-1}$ water was used for the herbicide application. Furadan (Carbofuran) was applied at rate of $10 \mathrm{~kg} \mathrm{ha}^{-1}$ with second irrigation and $10 \mathrm{~kg} \mathrm{ha}^{-1}$ with the third irrigation. During the whole growing season, uniform agronomic techniques were performed in all sub plots.

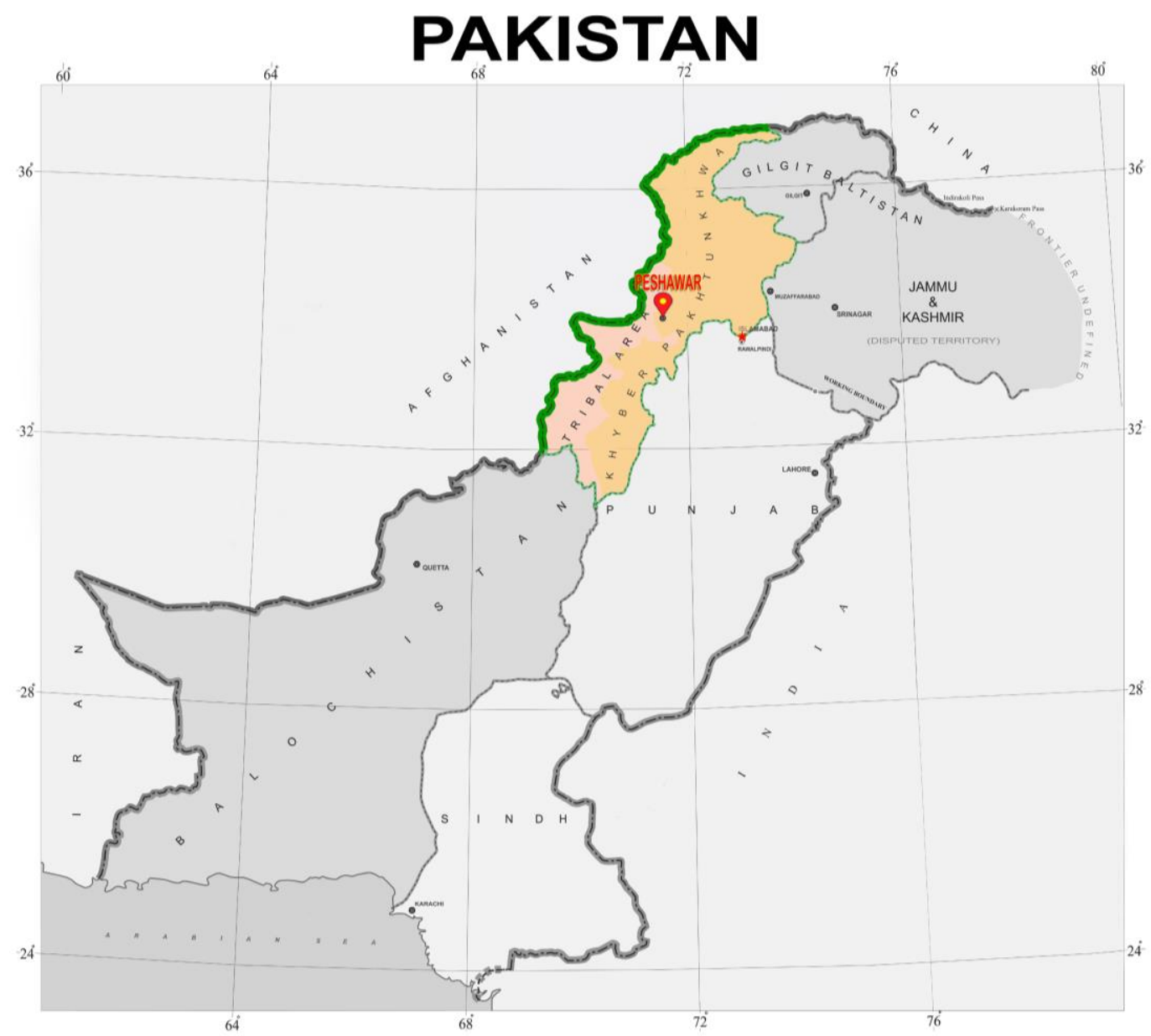

Figure 1. Location of the study site in the Peshawar city of Pakistan. (Modified from the source: www.surveyofpakistan.gov.pk)

Harvesting of whole plots was done manually on $15^{\text {th }}$ August 2017. After harvesting, plants were kept in the field for three days and then tied into bundles and stacked in the sun light for 3 weeks for sun-drying. After 3 weeks the ears of the whole plot were husked and allowed to dry in sunshine for two days. After sun-drying, husked ears were threshed by maize sheller and subsequent calculations were done to determine grain yields.

\section{Measurements}

\section{Phenological parameters}

Days to tasseling data were recorded by counting days from planting date to the date when $50 \%$ plants had produced tassels in each plot. Days to silking data were figured out in each plot by counting the number of days from sowing date to the date when $50 \%$ silks 
were appeared. Data on days to physiological maturity were recorded by counting the number of days between sowing date and the date when $50 \%$ plants in each plot get matured. The sign of physiological maturity i.e. dark brown/black abscission layer appearance in the base of seed was considered. For recording plant height $(\mathrm{cm})$ with the help of meter rod, five plants were randomly chosen at silking stage in each sub-plot and then averaged.

\section{Physiological traits}

For calculating CGR (Crop Growth Rate, $\mathrm{g} \mathrm{m}^{-2} \mathrm{~d}^{-1}$ ), one meter long row from side rows in each experimental unit was harvested and plants were oven-dried for $72 \mathrm{~h}$ at $70{ }^{\circ} \mathrm{C}$ to calculate their dry weight at, (1) V6 leaf stage, (2) Blister stage, and (3) R6 (Physiological maturity) stage. Formula used was:

$$
\operatorname{CGR}\left(\mathrm{g} \mathrm{m}^{-2} \mathrm{~d}^{-1}\right)=\left[\left(\mathrm{W}_{2}-\mathrm{W}_{1}\right) /\left(\mathrm{T}_{2}-\mathrm{T}_{1}\right) \times(1 / \mathrm{GA})\right]
$$

where, $\mathrm{W}_{1}=$ Initial weight at $27^{\text {th }}$ day after sowing; $\mathrm{W}_{2}=$ Last weight at $98^{\text {th }}$ day after sowing; $\mathrm{T}_{1}=$ Initial date $18^{\text {th }}$ May 2017 (Sowing); $\mathrm{T}_{2}=30^{\text {th }}$ August 2017 (Harvesting); $\mathrm{GA}=$ Row to row distance $(0.75 \mathrm{~cm}) \times$ plant to plant distance $(20 \mathrm{~cm}) \times$ number of plants (five plants)

Similarly, for absolute growth rate (AGR) one meter long row was selected from each plot was harvested and oven-dried for $72 \mathrm{~h}$ at $70{ }^{\circ} \mathrm{C}$ and then dry weight was determined at various growth stages viz. (1) V6 leaf stage, (2) Blister stage, and (3) R6 stage. AGR was figured out by the following formula:

$$
\operatorname{AGR}\left(\mathrm{g} \mathrm{m}^{-2} \mathrm{~d}^{-1}\right)=\mathrm{W}_{2}-\mathrm{W}_{1} / \mathrm{T}_{2}-\mathrm{T}_{1}
$$

where, $\mathrm{W}_{1}=$ weight at $27^{\text {th }}$ day after sowing; $\mathrm{W}_{2}=$ weight at $98^{\text {th }}$ day after sowing; $\mathrm{T}_{1}=$ date $18^{\text {th }}$ May 2017 (sowing); $\mathrm{T}_{2}=15^{\text {th }}$ August (harvesting).

Net assimilation arte (NAR) was calculated similarly as for CGR in each sub plot by selecting one meter long row from border rows, and harvested and oven-dried at $70{ }^{\circ} \mathrm{C}$ for $72 \mathrm{~h}$. Dry weight was found out at two growth stages, (1) V6 stage, and (2) R6 stage (physiological maturity). The following formula was used for NAR:

$$
\operatorname{NAR}\left(\mathrm{g} \mathrm{m}^{-2} \mathrm{~d}^{-1}\right)=\left[\mathrm{W}_{2}-\mathrm{W}_{1} / \mathrm{T}_{2}-\mathrm{T}_{1}\right] \times\left[\ln \mathrm{L}_{2}-\ln \mathrm{L}_{1} / \mathrm{L}_{2}-\mathrm{L}_{1}\right]
$$

where, $\mathrm{W}_{1}=$ weight at $27^{\text {th }}$ day after sowing; $\mathrm{W}_{2}=$ weight at $98^{\text {th }}$ day after sowing; $\mathrm{T}_{1}=$ date $18^{\text {th }}$ May 2017 (sowing); $\mathrm{T}_{2}=15^{\text {th }}$ August 2017 (harvesting); $\mathrm{L}_{1}=$ Initial leaf area at $18^{\text {th }}$ May 2017; $\mathrm{L}_{2}=$ final leaf area at $15^{\text {th }}$ August 2017.

\section{Chlorophyll contents at different stages}

From each experimental unit, five plants and three leaves per plant were randomly selected and sampled. The chlorophyll contents were measured out on three locations per leaf with chlorophyll meter (Model: SPAD-502, Minolta, Japan) and then averaged.

\section{Yield and yield attributes}

Ten ears were randomly chosen and sampled from each experimental unit and grains were counted and averaged. From these sampled ears, 1000 grains were randomly 
selected and weight was measured by electronic balance. At R6 stage, three central rows in each experimental unit were harvested manually by keeping sufficient border plants, fresh weight was measured and then sun-dried for $7 \mathrm{~d}$ and after that their dry weight was recorded. For calculating grain yield, all the ears from sun-dried plants of three central rows for each plot were threshed and weighed for calculating grain and biological yields, and for ear characteristics. The grain yields were adjusted to $15.5 \%$ grain moisture content and then presented. For each treatment, shelling percentage was estimated with the following formula:

Shelling percentage $=$ Grain weight of 10 ears $/$ Total weight of 10 ears $\times 100$

\section{Statistical analysis}

Data were statistically analyzed by analysis of variance (ANOVA) procedure suitable for randomized complete block design. Means were compared using least significant difference (LSD) test at 0.05 probability level, when F-values were significant (Steel et al., 1996). Interaction graphs were made through Sigma plot software (version 12.5).

\section{Results}

\section{Phenological parameters}

Irrigation, nitrogen, potassium and control vs rest significantly affected number of days to tasseling of maize, whereas all the interactions were found non-significant (Table 1). Means values of the data indicated that optimum irrigation significantly enhanced days to tasseling compared with reduced irrigation. Results revealed that lower $\mathrm{N}\left(100 \mathrm{~kg} \mathrm{ha}^{-1}\right)$ resulted in early tasseling. Days to tasseling were delayed with increase in nitrogen and maximum days to tasseling were noted with $250 \mathrm{~kg} \mathrm{~N} \mathrm{ha}^{-1}$. Potassium fertilization at the rate of $120 \mathrm{~kg} \mathrm{ha}^{-1}$ showed maximum days to tasseling which were statistically same to $160 \mathrm{~kg} \mathrm{~K} \mathrm{ha}^{-1}$ treatment, while less days to tasseling were recorded with $80 \mathrm{~kg} \mathrm{~K} \mathrm{ha}^{-1}$. Fertilized plots resulted in more days to tasseling compared with control plots.

Results revealed that days to silking were significantly influenced by nitrogen, potassium and control vs rest comparison, whereas irrigation and all the interactions were found non-significant (Table 2). Mean values for nitrogen showed that lower $\mathrm{N}$ $\left(120 \mathrm{~kg} \mathrm{ha}^{-1}\right)$ resulted in early silking, while delayed silking was observed with nitrogen application at the rate of $250 \mathrm{~kg} \mathrm{ha}^{-1}$. Maximum days to silking were noted with $160 \mathrm{~kg}$ $\mathrm{K} \mathrm{ha}^{-1}$ while less days to silking were recorded with potassium fertilization at the rate of 80. Data regarding physiological maturity was also effected by all treatments, while all the interactions were non-significant (Table 1). Optimum irrigation resulted in late physiological maturity compared to reduced irrigation. Mean values for nitrogen reported that minimum days to physiological maturity were observed with lower $\mathrm{N}$ $\left(100 \mathrm{~kg} \mathrm{ha}^{-1}\right)$ which were statistically identical to $150 \mathrm{~kg} \mathrm{~N} \mathrm{ha}^{-1}$. Increase in $\mathrm{N}$ had delayed the maturity and more days to physiological maturity were recorded for $250 \mathrm{~kg} \mathrm{~N} \mathrm{ha}^{-1}$. Potassium fertilization at the rate of $160 \mathrm{~kg} \mathrm{ha}^{-1}$ delayed physiological maturity while early maturity was observed with $80 \mathrm{~kg} \mathrm{~K} \mathrm{ha}^{-1}$. 
Table 1. Phenology of maize hybrid as influenced by fertilization of potassium and nitrogen under optimum and reduced irrigation

\begin{tabular}{c|c|c|c|c}
\hline & Days to tasseling & Days to silking & $\begin{array}{c}\text { Days to physiological } \\
\text { maturity }\end{array}$ & $\begin{array}{c}\text { Plant height } \\
\text { (cm) }\end{array}$ \\
\hline Potassium levels $\left(\mathrm{kg} \mathrm{ha}^{-1}\right)$ & & & & \\
80 & $49 \mathrm{~b}$ & $56 \mathrm{~b}$ & $93 \mathrm{c}$ & 192.3 \\
120 & $50 \mathrm{a}$ & $56 \mathrm{~b}$ & $94 \mathrm{~b}$ & 191.9 \\
160 & $50 \mathrm{a}$ & $57 \mathrm{a}$ & $95 \mathrm{a}$ & 192.3 \\
\hline LSD $(0.05)$ & 0.5 & 0.3 & 0.6 & $\mathrm{~ns}$ \\
\hline Nitrogen levels $\left(\mathrm{kg} \mathrm{ha}^{-1}\right)$ & & & & \\
100 & $48 \mathrm{c}$ & $55 \mathrm{~d}$ & $93 \mathrm{c}$ & $188.2 \mathrm{c}$ \\
150 & $49 \mathrm{~b}$ & $56 \mathrm{c}$ & $93 \mathrm{c}$ & $191.3 \mathrm{~b}$ \\
200 & $51 \mathrm{a}$ & $57 \mathrm{~b}$ & $95 \mathrm{~b}$ & $193.2 \mathrm{~b}$ \\
250 & $51 \mathrm{a}$ & $58 \mathrm{a}$ & $97 \mathrm{a}$ & $195.9 \mathrm{a}$ \\
\hline LSD $(0.05)$ & 0.6 & 0.4 & 0.7 & 2.6 \\
\hline Irrigation (I) & & & & \\
Optimum & 50 & 57 & 95 & 193.5 \\
Reduced & 49 & 56 & 94 & 190.8 \\
\hline LSD $(0.05)$ & $* *$ & $\mathrm{~ns}$ & $* *$ & $* *$ \\
\hline Control & 47 & 54 & 89 & 185.5 \\
Rest & 50 & 57 & 94 & 192.2 \\
\hline Interactions & Significance level & & & \\
N x K & $\mathrm{ns}$ & $\mathrm{ns}$ & & \\
K x I & $\mathrm{ns}$ & & & \\
N x I & $\mathrm{ns}$ & & & \\
K x N x I & ns & & \\
\hline
\end{tabular}

Means followed by different letter(s) of the same category are statistically significant using least significant differences (LSD) test at $\mathrm{P} \leq 0.05$. **: Significant at $0.05 \%$ probability. ns: non-significant

Plant height was also affected significantly due to irrigation and $\mathrm{N}$ treatments, whereas potassium and all the interactions were found non-significant (Table 1). Taller plants were produced by optimum irrigated plots. Mean values of the data revealed that nitrogen application at the rate of $100 \mathrm{~kg} \mathrm{ha}^{-1}$ resulted in shortest plants. Plant height increase with each increment of $\mathrm{N}$ and significantly tallest plants were recorded with $250 \mathrm{~kg} \mathrm{~N} \mathrm{ha}^{-1}$. The tallest plants were produced with $160 \mathrm{~kg} \mathrm{~K} \mathrm{ha}^{-1}$ treatment. Fertilized plots produced taller plants as compared to control plots.

\section{Growth parameters}

All the treatments had significantly affected the growth parameters at different stages, while all the interactions were found non-significant (Table 2). Results showed that S1 ( $1^{\text {st }}$ sampling stage) recorded with higher crop growth rate than S2 $\left(2^{\text {nd }}\right.$ sampling stage). Mean values of the data indicated that optimum irrigation significantly increased the crop growth rate compared to reduced irrigation treatment. Mean values for nitrogen revealed that lower $\mathrm{N}\left(100 \mathrm{~kg} \mathrm{ha}^{-1}\right)$ resulted in less crop growth rate. Crop growth rate increased with increase in $\mathrm{N}$ and significantly higher crop growth rate was recorded for $250 \mathrm{~kg} \mathrm{~N} \mathrm{ha}^{-1}$. Potassium application at the rate of $160 \mathrm{~kg} \mathrm{ha}^{-1}$ resulted in more crop 
growth rate while less crop growth rate was observed with $80 \mathrm{~kg} \mathrm{~K} \mathrm{ha}^{-1}$. The treatment $120 \mathrm{~kg} \mathrm{~K} \mathrm{ha}^{-1}$ was statistically similar to the highest $\mathrm{K}$ application treatment. Fertilized plots resulted in more crop growth rate compared to control plots.

Table 2. Growth indices of maize hybrid as influenced by fertilization of potassium and nitrogen under optimum and reduced irrigation

\begin{tabular}{|c|c|c|c|}
\hline & $\begin{array}{l}\text { Crop growth rate } \\
\left(\mathrm{g} \mathrm{m}^{-2} \mathrm{day}^{-1}\right)\end{array}$ & $\begin{array}{c}\text { Absolute growth rate } \\
\left(\mathrm{g} \mathrm{m}^{-2} \mathrm{day}^{-1}\right)\end{array}$ & $\begin{array}{l}\text { Net assimilation rate } \\
\left(\mathrm{g} \mathrm{m}^{-2} \mathrm{day}^{-1}\right)\end{array}$ \\
\hline \multicolumn{4}{|c|}{ Potassium levels $\left(\mathrm{kg} \mathrm{ha}^{-1}\right)$} \\
\hline 80 & $14.59 \mathrm{~b}$ & $7.59 \mathrm{~b}$ & $2.10 \mathrm{~b}$ \\
\hline 120 & $15.28 \mathrm{ab}$ & $8.22 \mathrm{ab}$ & $2.22 \mathrm{a}$ \\
\hline 160 & $16.17 \mathrm{a}$ & $9.24 \mathrm{a}$ & $2.23 \mathrm{a}$ \\
\hline $\operatorname{LSD}(0.05)$ & 1.12 & 1.06 & 0.11 \\
\hline \multicolumn{4}{|c|}{ Nitrogen levels $\left(\mathrm{kg} \mathrm{ha}^{-1}\right)$} \\
\hline 100 & $14.12 \mathrm{~b}$ & $7.03 \mathrm{c}$ & $1.95 \mathrm{~d}$ \\
\hline 150 & $14.55 \mathrm{~b}$ & $7.55 \mathrm{bc}$ & $2.10 \mathrm{c}$ \\
\hline 200 & $15.60 \mathrm{~b}$ & $8.68 \mathrm{~b}$ & $2.26 \mathrm{~b}$ \\
\hline 250 & $17.13 \mathrm{a}$ & $10.13 \mathrm{a}$ & $2.42 \mathrm{a}$ \\
\hline $\operatorname{LSD}(0.05)$ & 1.29 & 1.23 & 0.13 \\
\hline \multicolumn{4}{|l|}{ Irrigation } \\
\hline Optimum & 15.37 & 8.46 & 2.2 \\
\hline Reduced & 14.85 & 7.82 & 2.07 \\
\hline $\operatorname{LSD}(0.05)$ & $*$ & $*$ & $* * *$ \\
\hline \multicolumn{4}{|l|}{ Stages } \\
\hline S1 & $16.91 \mathrm{a}$ & $9.91 \mathrm{a}$ & $2.20 \mathrm{a}$ \\
\hline S2 & $13.30 \mathrm{~b}$ & $6.37 \mathrm{~b}$ & $2.07 \mathrm{~b}$ \\
\hline LSD (0.05) & $* * *$ & $* * *$ & **** \\
\hline Control & 12.19 & 5.62 & 1.56 \\
\hline Rest & 15.35 & 8.35 & 2.18 \\
\hline Interactions & Significance level & Interactions & Significance level \\
\hline $\mathrm{S} \times \mathrm{I}$ & $\mathrm{ns}$ & $\mathrm{I} \times \mathrm{N}$ & ns \\
\hline $\mathrm{K} \times \mathrm{N}$ & $\mathrm{ns}$ & $\mathrm{I} \times \mathrm{K} \times \mathrm{N}$ & $\mathrm{ns}$ \\
\hline $\mathrm{S} \times \mathrm{K}$ & ns & $S \times I \times K$ & ns \\
\hline $\mathrm{S} \times \mathrm{N}$ & $\mathrm{ns}$ & $S \times I \times N$ & $\mathrm{~ns}$ \\
\hline $\mathrm{S} \times \mathrm{K} \times \mathrm{N}$ & ns & $S \times I \times K \times N$ & ns \\
\hline I x K & $\mathrm{ns}$ & & \\
\hline
\end{tabular}

Means followed by different letter(s) of the same category are statistically significant using least significant differences (LSD) test at $\mathrm{P} \leq 0.05 .{ }^{*}, * * *$ : Significant at $0.05 \%$ probability. ns: nonsignificant

All treatments and stages significantly affected absolute growth rate (AGR) of maize, while all the interactions were found non-significant (Table 2). Results showed that S1 produce more AGR than S2. Mean values of the data indicated that optimum irrigation significantly produced more AGR. AGR increased with increase in $\mathrm{N}$ and significantly more values were recorded with $250 \mathrm{~kg} \mathrm{~N}^{-1}$. Potassium application at the rate of $160 \mathrm{~kg} \mathrm{ha}^{-1}$ was found with maximum AGR, and was similar to $120 \mathrm{~kg} \mathrm{~K} \mathrm{ha}^{-1}$. 
Almost same trend was found for net assimilation rate (NAR) of maize (Table 2). Results showed that S1 produce more NAR than S2. Amongst N treatments, $250 \mathrm{~kg} \mathrm{~N} \mathrm{ha}^{-1}$ was found maximum and $\mathrm{K}$ application at the rate of $160 \mathrm{~kg} \mathrm{ha}^{-1}$ resulted in maximum NAR, and was to $120 \mathrm{~kg} \mathrm{~K} \mathrm{ha}^{-1}$.

\section{Chlorophyll contents at different stages}

All the treatments and the control vs rest significantly affected chlorophyll contents at tasseling stage of maize, while all the interactions were found non-significant (Table 3). Lower $\mathrm{N}\left(100 \mathrm{~kg} \mathrm{ha}^{-1}\right)$ resulted in less chlorophyll contents at tasseling stage. Whereas, $250 \mathrm{~kg} \mathrm{~N}^{-1}$ produced maximum chlorophyll contents at tasseling stage. Optimum irrigation and the potassium application at the rate of $160 \mathrm{~kg} \mathrm{ha}^{-1}$ resulted in more chlorophyll contents at tasseling stage.

Table 3. Chlorophyll contents (SPAD values) of maize hybrid as influenced by fertilization of potassium and nitrogen under optimum and reduced irrigation

\begin{tabular}{c|c|c|c}
\hline & $\begin{array}{c}\text { Chlorophyll content at } \\
\text { tasseling }\end{array}$ & $\begin{array}{c}\text { Chlorophyll content } \\
\text { at silking }\end{array}$ & $\begin{array}{c}\text { Chlorophyll content at } \\
\text { grain formation }\end{array}$ \\
\hline Potassium levels $\left(\mathrm{kg} \mathrm{ha}^{-1}\right)$ & $50 \mathrm{c}$ & $52 \mathrm{c}$ & $48 \mathrm{c}$ \\
80 & $53 \mathrm{~b}$ & $55 \mathrm{~b}$ & $51 \mathrm{~b}$ \\
120 & $56 \mathrm{a}$ & $58 \mathrm{a}$ & $54 \mathrm{a}$ \\
160 & 3 & 3 & 3 \\
\hline LSD $(0.05)$ & & & $44 \mathrm{~d}$ \\
\hline Nitrogen levels $\left(\mathrm{kg} \mathrm{ha}^{-1}\right)$ & $46 \mathrm{~d}$ & $48 \mathrm{~d}$ & $48 \mathrm{c}$ \\
100 & $50 \mathrm{c}$ & $52 \mathrm{c}$ & $51 \mathrm{~b}$ \\
150 & $53 \mathrm{~b}$ & $55 \mathrm{~b}$ & $60 \mathrm{a}$ \\
200 & $62 \mathrm{a}$ & $64 \mathrm{a}$ & 3 \\
250 & 3 & 3 & 51 \\
\hline LSD $(0.05)$ & & & 50 \\
\hline Irrigation & 53 & 55 & $* *$ \\
Optimum & 52 & 54 & 42 \\
Reduced & $* *$ & $* *$ & 51 \\
\hline LSD $(0.05)$ & 44 & 46 & \\
\hline Control & 53 & 55 & \\
Rest & & Significance level & \\
\hline Interactions & & $\mathrm{ns}$ & \\
N x K & & $\mathrm{ns}$ & $\mathrm{ns}$ \\
K x I & & $\mathrm{ns}$ & \\
$\mathrm{N}$ x I & & & \\
K x N x I & & &
\end{tabular}

Means followed by different letter(s) of the same category are statistically significant using least significant differences (LSD) test at $\mathrm{P} \leq 0.05$. ${ }^{* *}$ : Significant at $0.05 \%$ probability. ns: non-significant

Almost the same results pattern for treatments were found for the SPAD values at later stages of silking and grain formation, as recorded for tasseling stage. We observed that silking stage was recorded with maximum SPAD values (chlorophyll contents) as compared to other two stages (Table 3). 


\section{Yield and yield attributes}

Data concerning grains $e^{-1}$ of maize showed that all the treatments (I, N, K) significantly influenced grains ear $^{-1}$, whereas all the interactions were found nonsignificant (Table 4). More number of grains ear $^{-1}$ were produced by optimum irrigated plots. $\mathrm{N}$ fertilization at the rate of $100 \mathrm{~kg} \mathrm{ha}^{-1}$ produced less grains ear ${ }^{-1}$. Grains ear ${ }^{-1}$ increased with increase in nitrogen up to $150 \mathrm{~kg} \mathrm{ha}^{-1}$. Thereafter, no increase in grains ear $^{-1}$ were observed with further increase in $\mathrm{N}$ level. Maximum number of grains ear ${ }^{-1}$ were produced when potassium was applied at the rate of $160 \mathrm{~kg} \mathrm{ha}^{-1}$ which was statistically similar with $120 \mathrm{~kg} \mathrm{~K} \mathrm{ha}^{-1}$. Fertilized plots produced more grains ear ${ }^{-1}$ in contrast to unfertilized plots.

Table 4. Agronomic traits of maize hybrid as influenced by fertilization of potassium and nitrogen under optimum and reduced irrigation

\begin{tabular}{|c|c|c|c|c|c|}
\hline & Grains ear $^{-1}$ & $\begin{array}{l}\text { 1000-grain } \\
\text { weight (g) }\end{array}$ & $\begin{array}{l}\text { Biological yield } \\
\left(\mathrm{kg} \mathrm{ha}^{-1}\right)\end{array}$ & $\begin{array}{c}\text { Shelling } \\
\text { percentage }(\%)\end{array}$ & $\begin{array}{c}\text { Grain yield } \\
\left(\mathrm{kg} \mathrm{ha}^{-1}\right)\end{array}$ \\
\hline \multicolumn{6}{|l|}{ Potassium levels $\left(\mathrm{kg} \mathrm{ha}^{-1}\right)$} \\
\hline 80 & $373 \mathrm{~b}$ & $241 \mathrm{~b}$ & $10752 \mathrm{~b}$ & $75.50 \mathrm{c}$ & $3847 \mathrm{c}$ \\
\hline 120 & $382 \mathrm{a}$ & $247 \mathrm{a}$ & $11260 \mathrm{a}$ & $78.60 \mathrm{~b}$ & 4068 a \\
\hline 160 & $386 \mathrm{a}$ & $246 \mathrm{a}$ & $11145 \mathrm{a}$ & $81.78 \mathrm{a}$ & $3981 \mathrm{~b}$ \\
\hline LSD (0.05) & 6 & 3.4 & 188 & 2.77 & 50 \\
\hline \multicolumn{6}{|l|}{ Nitrogen levels $\left(\mathrm{kg} \mathrm{ha}^{-1}\right)$} \\
\hline 100 & $350 \mathrm{c}$ & $232 \mathrm{c}$ & $10493 \mathrm{c}$ & $71.58 \mathrm{~d}$ & $3515 \mathrm{~d}$ \\
\hline 150 & $397 \mathrm{a}$ & $251 \mathrm{a}$ & $11111 \mathrm{~b}$ & $75.61 \mathrm{c}$ & 4193 a \\
\hline 200 & $386 \mathrm{~b}$ & $247 \mathrm{~b}$ & $11281 \mathrm{ab}$ & $78.92 \mathrm{~b}$ & $4121 \mathrm{~b}$ \\
\hline 250 & $388 \mathrm{~b}$ & $249 \mathrm{ab}$ & $11323 \mathrm{a}$ & $88.42 \mathrm{a}$ & $4031 \mathrm{c}$ \\
\hline LSD (0.05) & 7 & 3.9 & 204 & 3.19 & 58 \\
\hline \multicolumn{6}{|l|}{ Irrigation } \\
\hline Optimum & 384 & 248 & 11179 & 79.08 & 4059 \\
\hline Reduced & 378 & 241 & 10924 & 78.18 & 3871 \\
\hline $\operatorname{LSD}(0.05)$ & $* *$ & $* *$ & $* *$ & $* *$ & $* *$ \\
\hline Control & 354 & 225 & 8802 & 69.5 & 2388 \\
\hline Rest & 381 & 245 & 11052 & 78.63 & 3965 \\
\hline \multicolumn{6}{|l|}{ Interactions } \\
\hline $\mathrm{N} \times \mathrm{K}$ & ns & ns & $* *($ Fig. 2) & $\mathrm{ns}$ & $* *($ Fig. 3) \\
\hline $\mathrm{K} \times \mathrm{I}$ & $\mathrm{ns}$ & $\mathrm{ns}$ & ns & $\mathrm{ns}$ & $\mathrm{ns}$ \\
\hline $\mathrm{N} \times \mathrm{I}$ & ns & $\mathrm{ns}$ & $\mathrm{ns}$ & ns & $\mathrm{ns}$ \\
\hline $\mathrm{K} \times \mathrm{N} \times \mathrm{I}$ & ns & $\mathrm{ns}$ & $\mathrm{ns}$ & $\mathrm{ns}$ & $\mathrm{ns}$ \\
\hline
\end{tabular}

Means followed by different letter (s) of the same category are statistically significant using least significant differences (LSD) test at $\mathrm{P} \leq 0.05$. **: significant at $0.05 \%$ probability. ns: non-significant

Irrigation (I), nitrogen $(\mathrm{N})$, potassium $(\mathrm{K})$, control vs rest and $\mathrm{K} \times \mathrm{N}$ interaction significantly affected thousand grains weight of maize, whereas other interactions were found non-significant (Table 4). Optimum irrigation significantly produced heavier grains compared to reduced irrigation. Whereas, lower $\mathrm{N}\left(100 \mathrm{~kg} \mathrm{~N} \mathrm{ha}{ }^{-1}\right)$ resulted in lighter grains. Grain weight increases with increase in $\mathrm{N}$ up to $150 \mathrm{~kg} \mathrm{~N} \mathrm{ha}^{-1}$ which was statistically similar with $250 \mathrm{~kg} \mathrm{~N} \mathrm{ha}^{-1}$. Thereafter, no increase in thousand grains 
weight was noted with increase in $\mathrm{N}$ level. Potassium application at the rate of $120 \mathrm{~kg} \mathrm{ha}^{-1}$ resulted in more thousand grains weight which was statistically similar to $160 \mathrm{~kg} \mathrm{~K} \mathrm{ha}^{-1}$.

Irrigation $(\mathrm{I})$, nitrogen $(\mathrm{N})$, potassium $(\mathrm{K})$, control vs rest and $\mathrm{K} \times \mathrm{N}$ interaction significantly affected biological yield of maize (Table 4). Optimum irrigation remained superior in this regard. Mean values for nitrogen revealed that lower $\mathrm{N}$ resulted in less biological yield. Biological yield increase with increase in $\mathrm{N}$ and significantly more biological yield was recorded with $250 \mathrm{~kg} \mathrm{~N}^{-1}$ which was statistically similar with $200 \mathrm{~kg} \mathrm{~N} \mathrm{ha}{ }^{-1}$. Potassium application at the rate of $120 \mathrm{~kg} \mathrm{ha}^{-1}$ resulted in more biological yield which was statistically similar to $160 \mathrm{~kg} \mathrm{~K} \mathrm{ha}^{-1} . \mathrm{K} \times \mathrm{N}$ interaction represented that application of $\mathrm{K}$ at the rate of $80 \mathrm{~kg} \mathrm{ha}^{-1} \times 100 \mathrm{~kg} \mathrm{~N} \mathrm{ha}^{-1}$ produced less biological yield. Biological yield increased up to $80 \mathrm{~kg} \mathrm{~K} \mathrm{ha}^{-1} \times 150 \mathrm{~kg} \mathrm{~N} \mathrm{ha}^{-1}$. Thereafter, no increase in biological yield was noted with increase in $\mathrm{N}$ level. In case of $120 \mathrm{~kg} \mathrm{~K} \mathrm{x} \mathrm{N}$, biological yield increased linearly with increase in $\mathrm{N}$ up to $200 \mathrm{~kg} \mathrm{~N} \mathrm{ha}^{-1}$, thereafter a slight decrease in biological yield was noted with increase in $\mathrm{N}$ level up to $250 \mathrm{~kg} \mathrm{ha}^{-1}$. Similarly in case of $160 \mathrm{~kg} \mathrm{~K} \mathrm{x} \mathrm{N}$, biological yield increased linearly with increase in $\mathrm{N}$ up to $150 \mathrm{~kg} \mathrm{~N}^{-1}$, thereafter a slight increase in biological yield was noted with increase in $\mathrm{N}$ level up to $250 \mathrm{~kg} \mathrm{ha}^{-1}$ (Fig. 2).

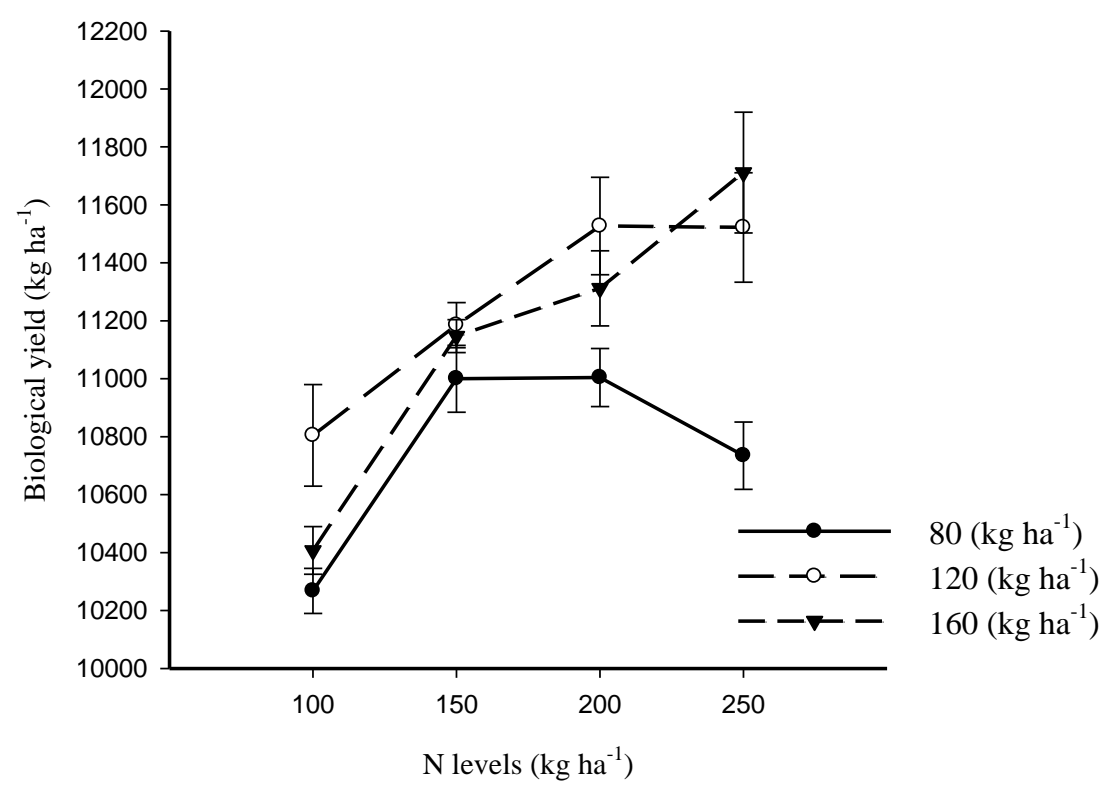

Figure 2. Interactive response of $K$ and $N$ on biological yield $\left(\mathrm{kg} \mathrm{ha}^{-1}\right)$

Irrigation $(\mathrm{I})$, nitrogen $(\mathrm{N})$, potassium $(\mathrm{K})$, control vs rest and $\mathrm{K} \times \mathrm{N}$ interaction significantly affected grain yield of maize, whereas other interactions were found nonsignificant (Table 4). $\mathrm{K} \times \mathrm{N}$ interaction represented that application of $\mathrm{K}$ at the rate of $80 \mathrm{~kg} \mathrm{ha}^{-1} \times 100 \mathrm{~kg} \mathrm{~N} \mathrm{ha}^{-1}$ produced less grain yield. Grain yield increased up to $80 \mathrm{~kg}$ $\mathrm{K} \mathrm{ha}^{-1} \times 150 \mathrm{~kg} \mathrm{~N} \mathrm{ha}^{-1}$. Thereafter, no increase in grain yield was noted with increase in $\mathrm{N}$ level. In case of $120 \mathrm{~kg} \mathrm{~K} \times \mathrm{N}$, grain yield increased with increase in $\mathrm{N}$ up to $150 \mathrm{~kg}$ $\mathrm{N} \mathrm{ha}^{-1}$, thereafter a slight decrease in grain yield was noted with increase in $\mathrm{N}$ level up to $250 \mathrm{~kg} \mathrm{ha}^{-1}$. Similarly in case of $160 \mathrm{~kg} \mathrm{~K} \times \mathrm{N}$, grain yield increased with increase in $\mathrm{N}$ up to $150 \mathrm{~kg} \mathrm{~N} \mathrm{ha}^{-1}$, thereafter a slight decrease in grain yield was noted with increase in $\mathrm{N}$ level up to $250 \mathrm{~kg} \mathrm{ha}^{-1}$ (Fig. 3). 


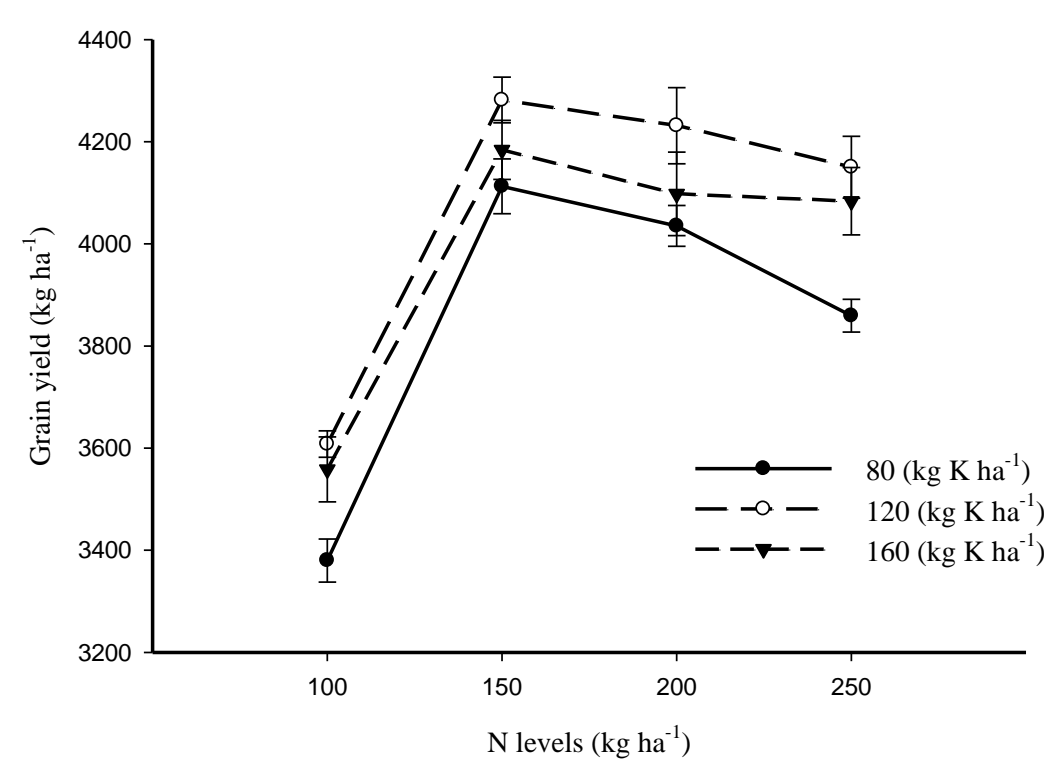

Figure 3. Interactive response of $K$ and $N$ on grain yield $\left(\mathrm{kg} \mathrm{ha}^{-1}\right)$

Irrigation $(\mathrm{I})$, nitrogen $(\mathrm{N})$, potassium $(\mathrm{K})$ and control vs rest significantly affected shelling percentage of maize, while all the interactions were found non-significant (Table 4). Optimum irrigation significantly recorded with maximum shelling percentage. Shelling percentage increased with increase in $\mathrm{N}$ and significantly more shelling percentage was recorded with $250 \mathrm{~kg} \mathrm{~N}^{-1}$. Potassium application at the rate of $160 \mathrm{~kg} \mathrm{ha}^{-1}$ resulted in more shelling percentage while less shelling percentage was observed with $80 \mathrm{~kg} \mathrm{~K} \mathrm{ha}^{-1}$. Fertilized plots resulted in more shelling percentage compared with control plots.

\section{Discussion}

\section{Effect of $N$ and $K$ on phenology of maize under optimum and reduced irrigation}

Delayed tasseling was observed with higher levels of nitrogen and potash. This delayed phenology with increasing $\mathrm{N}$ levels could be attributed to the impact of $\mathrm{N}$ on vegetative growth of maize crop, and photosynthetic performance (Ma et al., 2015), that might had increased leaf longevity and ultimately phenological development (Wang et al., 2017). These results are in full accordance with that of Peng et al. (2017) who observed delayed phenology with higher levels of $\mathrm{N}$. Likewise, delayed tasseling under high level of potassium could be attributed to the role of potassium in stomata regulation and photosynthetic activity (Shah et al., 2017). These results were supported by Zamir et al. (2015) who observed delayed tasseling from plots having higher levels of potash. The optimum irrigation level had delayed days to tasseling in comparison with reduced irrigation which could be attributed to hormonal changes and greater availability of $\mathrm{N}$ and K (Alfredo and Setter, 2000). Delayed silking in plots treated with higher levels of $\mathrm{N}$ might be attributed to vigorous vegetative growth in response to higher nitrogen use efficiency that might had delayed the silking (Sharifi and Namvar, 2016). These results are also supported by Muller et al. (2017), as they observed delayed silking with increasing levels of N. Delayed silking with higher levels of $\mathrm{K}$ are further evidenced by Aslam et al. (2014). 
Delayed maturity in plots treated with higher levels of $\mathrm{N}$ could be attributed to prolonged vegetative growth. This prolong vegetative growth might be attributed to retention of green leaf, higher chlorophyll contents, and greater photosynthetic performance (Zhang et al., 2014). Higher rates of $\mathrm{N}$ delayed leaf senescence and uphold extended photosynthetic performance that might have delayed the maturity (Arif et al., 2012). These results are in line with that of Ali et al. (2012), who observed delayed physiological maturity from plots treated with higher $\mathrm{N}$ levels. The delayed maturity under higher $\mathrm{K}$ levels could be attributed to improved water use efficiency and higher uptake of nutrients that extended the vegetative growth and delayed maturity (Hati et al., 2006). These results are in line with Iqbal et al. (2016), who observed delayed physiological maturity with higher $\mathrm{K}$ levels. Although plant height is genetically controlled character however, it is also influenced from environment and management practices (Achieng et al., 2010). Taller plants in plots treated with higher levels of $\mathrm{N}$ might be related to impact of $\mathrm{N}$ on enzymatic and photosynthetic activities as well as cell division and stem elongation (Cechin and Fumis, 2004). The report of Achieng et al. (2010) are in full accord with our finding. The taller plants obtained from optimum irrigation could be attributed to better physiological activities and improved plant growth (Gaveh et al., 2011). Our results are also in line with that of Cakir (2004).

\section{Effect of $N$ and $K$ on growth indices of maize under optimum and reduced irrigation}

The higher crop growth rate in response to optimum nitrogen application is attributed to higher leaf area and leaf area index and higher chlorophyll contents (Azarpour et al., 2014). The higher level of nitrogen promotes hormonal activities in plants that enhance the vegetative growth and leaves enlargement (Azarpour et al., 2014). The higher crop growth rate in early stages compared to later stages of plant development is supported by Peng et al. (2017). The higher CGR means greater dry matter is accumulated by plants per unit area per unit time as a result of enhanced photosynthetic efficiency which might increase in response to higher levels of potassium application and optimum irrigation (Inthichack et al., 2012). These results are supported by Antony and Singandhupe (2004) who observed greater plant growth and final yield in response to optimum irrigation regime. Al-Omran et al. (2010) reported that optimum water supply is essential for higher crop growth, which is in accordance with our findings.

The higher net accumulation rate and absolute growth rate of maize crop was observed from application of higher levels of $\mathrm{N}$ and $\mathrm{K}$ as well as optimum irrigation. The higher concentration of nitrogen and potassium might had increased enzymatic activities responsible for translocation of assimilates towards the economic portion (Zhong et al., 1997). The higher rates of $\mathrm{N}$ and $\mathrm{K}$ had increased the dry matter of plants through increased photosynthates production that might had increased the net accumulation rates. Likewise optimum irrigation might had improved the leaf longevity that might results in optimum NAR compared with reduced irrigation (Amanullah and Khalid, 2016). These results are in line with that of Azizian and Sepaskah et al. (2014). The maximum shelling percentage of maize crop was observed from higher levels of nitrogen and potash as well as optimum irrigation treatment was due to optimum leaf area and chlorophyll contents that might had increased the physiological parameters i.e. CGR, NAR and AGR, thus resulting in maximum translocation of assimilates towards the economic portion. This higher translocation of assimilates might had improved the shelling percentage. These results are further supported by the findings of Shah et al. (2017). 


\section{Effect of $N$ and $K$ on chlorophyll contents of maize under optimum and reduced irrigation}

The increased chlorophyll contents of maize leaf in response to increasing levels of nitrogen might be attributed to the impact of nitrogen on leaf growth and leaf area (Bojovic and Markovic, 2009). The same authors reported a high correlation between nitrogen application and leaf chlorophyll contents. It was reported that nitrogen is the structural element of protein and chlorophyll molecule, and its higher concentrations had proved to increase the chloroplast formation and leaf photosynthetic efficiency (Shah et al., 2017). Hokmalipour and Darbandi (2011) reported that nitrogen fertilization activates the enzymes associated with chlorophyll formation thus results in higher concentration of chlorophyll than control plots. These results are in full accordance with that of Ciompi et al. (1996) and Zhao et al. (2005). The higher chlorophyll contents in plots treated with higher levels of potassium might be associated with better nitrogen uptake under higher $\mathrm{N}$ levels (Peng et al., 2017). Potassium is essential for chlorophyll formation, stomatal conductance and RuBP case activities, thus it had great impact on photosynthesis (Liu et al., 2009). These results are further supported by Shah et al. (2017). The maximum chlorophyll content in response to optimum irrigation is supported by Liu et al. (2005).

\section{Effect of $N$ and $K$ on agronomic traits of maize under optimum and reduced irrigation}

Number of grains ear ${ }^{-1}$ was significantly affected by $\mathrm{N}, \mathrm{K}$ and irrigation levels. Optimum number of grains ear $^{-1}$ was recorded from plots having $180 \mathrm{~kg} \mathrm{~N} \mathrm{ha}^{-1}$. This increase could be attributed to greater seed row ear ${ }^{-1}$ and number of grains row $^{-1}$ (Hokmalipour and Darbandi, 2011) and maximum dry matter accumulation. These results are supported by Shah et al. (2017). The K fertilization has likely to increase the water use efficiency of crops under water limited conditions and hence increased the dry matter production and its ultimate partitioning towards the reproductive part of the plant, that might had increased the number of grains ear-1 (Iqbal et al., 2016). These results are supported by Shah et al. (2017) who observed higher number of grains ear ${ }^{-1}$ from increasing $\mathrm{K}$ levels.

Higher thousand grains weight and grain yield from plots treated with $180 \mathrm{~kg} \mathrm{~N}^{-1}$ might be attributed to higher chlorophyll contents associated with higher leaf area, that might had increased the photosynthetic efficiency and assimilates production and its availability during grains filling stage (Manzoor et al., 2006). The higher assimilates production through photosynthesis and its efficient partitioning towards the grain might had increased the yield and yield components of maize (Khan et al., 2014b). These results are fully supported by the results reported by Hokmalipour and Darbandi (2011). The increased yield and yield components of maize in response to higher levels of $\mathrm{K}$ might be attributed to the role of $\mathrm{K}$ in increasing water use efficiency that might had increased the cell division, improved plant growth and efficiently translocate the photosynthates towards the grains (Shah et al., 2017). However Enujeke (2013) reported that accumulation of proteins and other reserves food might be the cause for increased yield. The probable reason for optimum yield with higher $\mathrm{K}$ levels could be more leaf area, delayed maturity and improved yield attributes (Iqbal et al., 2016), due to stabilized stomatal regulation, greater carbon dioxide assimilation and the more carbohydrate production (Zeidan and Kramany, 2001). The increase in grain yield with 
optimum irrigation have also been reported by Pandey et al. (2000) and Khan et al. (2014a). The combination of $\mathrm{N}$ and $\mathrm{K}$ had boosted 1000 grains weight and grain yield than their sole use. This increase in grain yield is also supported by the study of Shah et al. (2017).

The maximum biological yield in response to increasing levels of nitrogen might be attributed to better vegetative growth, greater leaf area and dry matter production (Keivanrad and Zandi, 2012) probably due to lower completion of plants for $\mathrm{N}$ and more even distribution of assimilates (Zangani et al., 2006). These results are in line with that of Imran et al. (2015), who observed maximum biological yield from higher doses of $\mathrm{N}$ fertilizer. Likewise the stover and biological yield was increased with increasing levels of potassium which might be attributed to the better plant growth due to the possible role of potassium in water balance, maintenance of turgor pressure, transportation of assimilates and disease resistance (Brar and Tiwari, 2004). The report of Hosinkhani et al. (2013) was also found in accordance with our findings. Shah et al. (2017) also reported similar results as ours. The optimum irrigation had increased the biological yield in comparison with reduced irrigation which might be explained with proper plant growth and better development due to moisture availability at sensitive stages of phonological development (Ngwako and Mashiqa, 2013). These results are supported by Hussain et al. (1996). The increase in biological yield with integrated use of $\mathrm{N}$ and P was supported by Khan et al. (2014a). Brar and Tiwari (2004) also observed the increase in biological yield of maize from integrated use of $\mathrm{N}$ and $\mathrm{P}$, and attributed this increase to greater nitrogen use efficiency.

\section{Conclusion}

On the basis of findings obtained in present work, it is concluded that optimum irrigation produced optimum plant growth, yield and yield attributes in maize. Application of $120 \mathrm{~kg} \mathrm{~K} \mathrm{ha}^{-1}$ had resulted in higher grain yields and yield components. Whereas, application of $150 \mathrm{~kg} \mathrm{~N} \mathrm{ha}^{-1}$ boosted maize yield and yield components to their optimum levels. Based on the results, application of $120 \mathrm{~kg} \mathrm{~K} \mathrm{ha}^{-1}$ along with $150 \mathrm{~kg} \mathrm{~N} \mathrm{ha}^{-1}$ is recommended for obtaining optimum growth, yield and yield attributes under optimum irrigation (five irrigations) for maize in agro-climatic conditions of the Peshawar, Pakistan. To strengthen our results, future studies should focus on optimizing the fertilizer $(\mathrm{N}, \mathrm{P}, \mathrm{K})$ rates by estimating the nutrient use efficiencies, with special emphasis on agronomic- and physiological-use efficiency for the maize hybrids being cultivated in major areas of Pakistan. In addition to nutrient recovery analysis, the data pertaining to the plant organ nutrient analysis for $\mathrm{N}, \mathrm{P}$ and $\mathrm{K}$ under different planting densities are vital for the Pakistani maize production system.

Acknowledgements. The publication of present work was supported by the National Key Research and Development Program of China (grant no. 2017YFC0504704) and the National Natural Science Foundation of China (51669034, 41761068, 51809224).

\section{REFERENCES}

[1] Achieng, J. O., Ouma, G., Odhiambo, G., Muyekho, F. (2010): Effect of farmyard manure and inorganic fertilizers on maize production on Alfisols and Ultisols in Kakamega, western Kenya. - Agri. Bio. J. North America 1(4): 430-439. 
[2] Ahmad, N., Rashid, M. (2003): Fertilizers and their use in Pakistan. Extension Bulletin. NDFC. Islamabad.

[3] Alfredo, A. C. A., Setter, T. L. (2000): Response of cassava to water deficit: Leaf area growth and abscisic acid. - Crop Sci. 40: 131-137.

[4] Ali, M., Ali, A., Tahir, M., Yaseen, M. (2012): Growth and yield response of hybrid maize through integrated phosphorus management. - Pak. J. Life Soc. Sci. 10(1): 59-66.

[5] Al-Omran, A. M., Al-Harbi, A. R., Wahb-Allah, M. A., Nadeem, M., Al-Eter, A. (2010): Impact of irrigation water quality, irrigation systems, irrigation rates and soil amendments on tomato production in sandy calcareous soil. - Turkish J. Agri. For. 34(1): 59-73.

[6] Amanullah (2004): Physiology partitioning of assimilates and yield of maize as affected by plant density rate and timing of nitrogen application. - Doctoral Dissertation, University of Agricultural, Peshawar, Pakistan.

[7] Amanullah, Khalid, S. (2016): Integrated Use of Phosphorus, Animal Manures and Biofertilizers Improve Maize Productivity under Semiarid Condition. - In: Larramendy, M. L., Soloneski, S. (eds.) Organic Fertilizers - From Basic Concepts to Applied Outcomes. InTech, Rijeka, pp. 137-155.

[8] Amanullah, Khan, M. W. (2010): Interactive effect of potassium and phosphorus on grain quality and profitability of sunflower in Northwest Pakistan. - Pedosphere 21(4): 532538.

[9] Amanullah, Hassan, M., Malhi, S. S. (2011): Seed yield and yield components response of rape (B. napus) versus mustard (B. juncea) to sulfur and potassium fertilizer application in Northwest Pakistan. - J. Plant Nutr. 34(8): 1164-1174.

[10] Amanullah, Kakar, K. M., Khan, A., Khan, I., Shah, Z., Hussain, Z. (2014): Growth and yield response of maize (Zea mays L.) to foliar NPK-fertilizers under moisture stress condition. - Soil Environ. 33: 116-123.

[11] Antony, E., Singandhupe, R. B. (2004): Impact of drip and surface irrigation on growth, yield and WUE of capsicum (Capsicum annum L.). - Agric. Water Manag. 65(2): 121132.

[12] Arif, M., Ali, K., Munsif, F., Ahmad, W., Ahmad, A., Naveed, K. (2012): Effect of biochar, FYM and nitrogen on weeds and maize phenology. - Pak. J. Weed Sci. Res. 18(4): 475-484.

[13] Aslam, M., Zamir, M. S. I., Afzal, I., Amin, M. (2014): Role of potassium in physiological functions of spring maize (Zea mays L.) grown under drought stress. - J. Anim Plant Sci. 24(5): 1452-1465.

[14] Azarpour, E., Moraditochaee, M., Bozorgi, H. R. (2014): Effect of nitrogen fertilizer management on growth analysis of rice cultivars. - Int. J. Biosci. 4(5): 35-47.

[15] Azizian, A., Sepaskhah, A. R. (2014): Maize response to different water, salinity and nitrogen levels: agronomic behavior. - Int. J. Plant Prod. 8(1): 107-130.

[16] Bojović, B., Marković, A. (2009): Correlation between nitrogen and chlorophyll content in wheat (Triticum aestivum L.). - Kragujevac J. Sci. 31: 69-74.

[17] Brar, M. S., Tiwari, K. N. (2004): Boosting seed cotton yields in Punjab with potassium: A review. - Better Crops 88(3): 28-31.

[18] Cakir, R. (2004): Effect of water stress at different development stages on vegetative and reproductive growth of corn. - Field Crops Res. 89(1): 1-16.

[19] Cechin, I., de Fátima Fumis, T. (2004): Effect of nitrogen supply on growth and photosynthesis of sunflower plants grown in the greenhouse. - Plant Sci. 166(5): 13791385.

[20] Ciompi, S., Gentili, E., Guidi, L., Soldatini, G. F. (1996): The effect of nitrogen deficiency on leaf gas exchange and chlorophyll fluorescence parameters in sunflower. Plant Sci. 118(2): 177-184.

[21] Earl, H. J., Davis, R. F. (2003): Effect of drought stress on leaf and whole canopy radiation use efficiency and yield of maize. - Agron J. 95(3): 688-696. 
[22] Enujeke, E. C. (2013): Effects of variety and spacing on growth characters of hybrid maize. - Asian J. Agri. Rur. Dev. 3: 296-310.

[23] Gaveh, E. A., Timpo, G. M., Agodzo, S. K., Shin, D. H. (2011): Effect of irrigation, transplant age and season on growth, yield and irrigation water use efficiency of the African eggplant. - Hort. Environ. Biotech. 52(1): 13-28.

[24] Hati, K. M., Mandal, K. G., Misra, A. K., Ghosh, P. K., Bandyopadhyay, K. K. (2006): Effect of inorganic fertilizer and farmyard manure on soil physical properties, root distribution, and water-use efficiency of soybean in Vertisols of central India. - Biores. Tech. 97(16): 2182-2188.

[25] Hokmalipour, S., Darbandi, M. H. (2011): Effects of nitrogen fertilizer on chlorophyll content and other leaf indicate in three cultivars of maize (Zea mays L.). - World App. Sci. J. 15(12): 1780-1785.

[26] Hosinkhani, A., M., Panahi Kordlaghari, K., Balouchi, H. R. (2013): Effects of potassium and iron nutrient elements on the quantity yield of Shariar wheat cultivar in Boyerahmad Reign. - Annals Biol Res. 4(4): 56-60.

[27] Huber, J. L., Redinbaugh, M. G., Huber, S. C., Campbell, W. H. (1994): Regulation of maize leaf nitrate reductase activity involves both gene expression and protein phosphorylation. - Plant Physiol. 106(4): 1667-1674.

[28] Hussain, G., Al-Jaloud, A. A., Karimulla, S. (1996): Effect of treated effluent irrigation and nitrogen on yield and nitrogen use efficiency of wheat. - Agric. Water Manag. 30(2): 175-184.

[29] Imran, S, Arif, M., Khan, A., Khan, M. A., Shah, W. et al. (2015): Effect of nitrogen levels and plant population on yield and yield components of maize. - Adv. Crop Sci. Tech. 3: 170. DOI: 10.4172/2329-8863.1000170.

[30] Inthichack, P., Nishimura, Y., Fukumoto, Y. (2012): Effect of potassium sources and rates on plant growth, mineral absorption, and the incidence of tip burn in cabbage, celery, and lettuce. - Hort. Environ. Biotech. 53(2): 135-142.

[31] Iqbal, S., Guber, A. K., Khan, H. Z. (2016): Estimating nitrogen leaching losses after compost application in furrow irrigated soils of Pakistan using HYDRUS-2D software. Agric. Water Manag. 168: 85-95.

[32] Keivanrad, S., Delkhosh, B., Shirani Rad, A. H., Zandi, P. (2012): The Effect of different rates of nitrogen and plant density on qualitative and quantitative traits of Indian mustard. - Adv. Environ. Biol. 6(1): 145-152.

[33] Khan, F., Khan, S., Fahad, S., Faisal, S., Hussain, S., Ali, S., Ali, A. (2014a): Effect of different levels of nitrogen and phosphorus on the phenology and yield of maize varieties. - American J. Plant Sci. 5(17): 2582.

[34] Khan, S. A., Mulvaney, R. L., Ellsworth, T. R. (2014b): The potassium paradox: Implications for soil fertility, crop production and human health. - Renewable Agri. Food Sys. 29(1): 3-27.

[35] Liu, J., Chen, F., Olokhnuud, C., Glass, A. D. M., Tong, Y., Zhang, F., Mi, G. (2009): Root size and nitrogen-uptake activity in two maize (Zea mays L.) inbred lines differing in nitrogen-use efficiency. - J. Plant Nutr. Soil Sci. 172(2): 230-236.

[36] Liu, X. J., Mosier, A. R., Halvorson, A. D., Zhang, F. S. (2005): Tillage and nitrogen application effects on nitrous and nitric oxide emissions from irrigated corn fields. - Plant Soil 276(1-2): 235-249.

[37] Ma, S. Y., Liu, Y. N., Wang, Y. Q., Qin, Y. N., Liu, H. L., Peng, Z. P. (2015): Study on the characters of living condition and nutrient balance of high-yield wheat and maize rotation system in Hebei province. - J. Agric. Univ. 38: 8-13.

[38] Marschner, H. (1995): Mineral Nutrition of Higher Plants. Ed. 2. - Academic Press, London.

[39] Marschner, P., Rengel, Z. (2012): Nutrient Availability in Soils. - In: Marschner, H. (ed.) Mineral Nutrition of Higher Plants (Third Edition). Elsevier/Academic Press, London, pp. 315-330. 
[40] Mengel, K., Kirkby, E. A., Kosegarten, H., Appel, T. (2001): Potassium. - In: Mengel, K., Kirkby, E. A. (eds.) Principles of Plant Nutrition (Vol. 2). Springer, Dordrecht, pp. 481-511.

[41] Mueller, S. M., Camberato, J. J., Messina, C., Shanahan, J., Zhang, H., Vyn, T. J. (2017): Late-split nitrogen applications increased maize plant nitrogen recovery but not yield under moderate to high nitrogen rates. - Agron. J. 109: 2689-2699.

[42] Ngwako, S., Mashiqa, P. K. (2013): The effect of irrigation on the growth and yield of winter wheat (Triticum aestivum L.) cultivars. - Int. J. Agri. Crop Sci. 5(9): 976.

[43] Noor, M. A. (2017): Nitrogen management and regulation for optimum NUE in maize-A mini review. - Cogent Food \& Agri. 3(1): 1348214.

[44] Noorka, I. R., Rehman, S., Haidry, J. R., Khaliq, I., Tabassam, S., Din, M. (2009): Effect of water stress on physico-chemical properties of wheat (Triticum aestivum L.). - Pak. J. Bot. 41(6): 2917-2924.

[45] Noorka, I. R., Hafiz, S. I., El-Bramawy, M. A. S. (2011): Response of sesame to population densities and nitrogen fertilization on newly reclaimed sandy soils. - Pak. J. Bot. 43(4): 1953-1958.

[46] Pandey, R. K., Maranville, J. W., Admou, A. (2000): Deficit irrigation and nitrogen effects on maize in a Sahelian environment. I. Grain yield and yield components. - Agric Water Manag. 46: 1-13.

[47] Peng, Z., Liu, Y., Li, Y., Abawi, Y., Wang, Y., Men, M., An-Vo, D.-A. (2017): Responses of nitrogen utilization and apparent nitrogen loss to different control measures in the wheat and maize rotation system. - Front. Plant Sci. 8: 160

[48] Romheld, V., Kirkby, E. A. (2010): Research on potassium in agriculture: Needs and prospects. - Plant Soil 335: 155-180.

[49] Rosenstock, N. P., Berner, C., Smits, M. M., Krám, P., Wallander, H. (2016): The role of phosphorus, magnesium and potassium availability in soil fungal exploration of mineral nutrient sources in Norway spruce forests. - New Phytol 211(2): 542-553.

[50] Scharf, P. C., Brouder, S. M., Hoeft, R. G. (2006): Chlorophyll meter readings can predict nitrogen need and yield response of corn in the north-central USA. - Agron. J. 98(3): 655-665.

[51] Shah, T., Khan, A. Z., Numan, M., Ahmad, W., Zahoor, M., Ullah, M., Jalal, A. (2017): Nutrient uptake and yield of wheat varieties as influenced by foliar potassium under drought condition. - Cercetari Agron. Moldova 50(2): 5-20.

[52] Sharifi, R. S., Namvar, A. (2016): Effects of time and rate of nitrogen application on phenology and some agronomical traits of maize (Zea mays L.). - Biologija 62(1): 35-45.

[53] Steel, R. G. D., Torrie, J. H. Dickey, D. (1996): Principals and Procedures of Statistics. Mc Graw Hill, USA.

[54] Wang, M., Zheng, Q., Shen, Q., Guo, S. (2013): The critical role of potassium in plant stress response. - Int. J. Mol. Sci. 14(4): 7370-7390.

[55] Wang, X. G., Zhao, X. H., Jiang, C. J., Li, C. H., Shan, C. O. N. G., Di, W. U., Wang, C. Y. (2015): Effects of potassium deficiency on photosynthesis and photoprotection mechanisms in soybean (Glycine max (L.) Merr.). - J. Integ. Agri. 14(5): 856-863.

[56] Wang, X., Li, Z., Xing, Y. (2015): Effects of mulching and nitrogen on soil temperature, water content, nitrate-N content and maize yield in the Loess Plateau of China. - Agric. Water Manag. 161: 53-64.

[57] Wang, S., Wang, Z., Gu, J. (2017): Variation patterns of fine root biomass, production and turnover in Chinese forests. - J. For. Res. 28: 1185-1194.

[58] Wang, X., Fan, J., Xing, Y., Xu, G., Wang, H., Deng, J., Wang, Y., Zhang, F., Li, P., Li, Z. (2018a): The Effects of Mulch and Nitrogen Fertilizer on the Soil Environment of Crop Plants. - Adv. Agron. 153, https://doi.org/10.1016/bs.agron.2018.08.003.

[59] Wang, X., Yue, Y., Noor, M. A., Hou, H., Zhou, B., Ma, W., Zhao, M. (2018b): Tillage time affects soil hydro-thermal properties, seedling growth and yield of maize (Zea mays L.). - App. Eco. Environ. Res. 6007-6023. 
[60] White, P. J., Karley, A. J. (2010): Potassium. - In: Hell, R., Mendel, R.-R. (eds.) Cell Biology of Metals and Nutrients. Springer, Berlin, Heidelberg, pp. 199-224.

[61] Zamir, M. S. I., Aslam, M., Javeed, H. M. R. (2015): Influence of potassium levels on the phenology of maize (Zea mays L.) hybrids grown under drought stress. - Pak. J. Life Soc. Sci. 13(2): 1-7.

[62] Zangani, E., Kashani, A., Fathi, G. H., Mesgarbashi, M. (2006): Effect and efficiency of nitrogen levels on quantitative and qualitative yield and yield components of two cultivars of rapeseed in Ahwaz region. - Iranian J. Agric. Sci. 37(1): 39-45.

[63] Zeidan, M. S., Kramany, M. F. E. (2001): Effect of organic manure and slow-release Nfertilizers on the productivity of wheat in sandy soil. - Agron. Hung. 49: 379-385.

[64] Zhang, S., Sadras, V., Chen, X., Zhang, F. (2014): Water use efficiency of dryland maize in the Loess Plateau of China in response to crop management. - Field Crops Res. 163: $55-63$.

[65] Zhao, D., Reddy, K. R., Kakani, V. G., Reddy, V. R. (2005): Nitrogen deficiency effects on plant growth, leaf photosynthesis, and hyperspectral reflectance properties of sorghum. - Europ. J. Agron. 22(4): 391-403.

[66] Zhong, N. W., Song, Z. Y., Yong, L. X. (1997): The effect of different K sources on yield and quality of some vegetable crops. - Acta Agric. Zhejiangesis 9(3): 143-148. 